\title{
Method for Sediment Texture Characterization Using Spectroscopy Techniques and Multivariate Analysis
}

\author{
Melquiades, F. L.; ${ }^{*}$ González-Borrero, P. P.; dos Santos, F. R.; de Deus, W. \\ E. D.; Kalwa, M.; Quináia, S. P.
}

Rev. Virtual Quim., 2014, 6 (6), 1687-1701. Data de publicação na Web: 11 de dezembro de 2014

http://www.uff.br/rvq

\section{Método para Caracterização de Textura de Sedimentos Usando Técnicas Espectroscópicas e Análise Multivariada}

\begin{abstract}
Resumo: O objetivo deste estudo foi apresentar um método para caracterização da textura de sedimentos combinando três técnicas espectroscópicas com analise multivariada. Em particular, foram utilizados dados de medidas de espectroscopia de absorção atômica de chama (FAAS), fluorescência de raios $X$ por dispersão em energia (EDXRF) e espectroscopia fotoacústica (PAS) em amostras de sedimento superficial de lago, os quais foram combinados com o método de análise de componentes principais para a analise exploratória de dados e o método de regressão dos mínimos quadrados parciais (PLS) para a estimativa indireta da textura dos sedimentos. Foi possível inferir valores quantitativos de tamanho de partícula usando dados das três técnicas aliada a regressão por PLS, a qual permitiu obter dados implícitos em cada conjunto de dados. A mesma classificação em função da textura das amostras foi verificada para todas as técnicas espectroscópicas. No entanto, a classificação por EDXRF ou PAS foi mais simples, rápida, barata e não destrutiva quando comparada com a FAAS. No caso da previsão quantitativa da granulometria pela regressão por PLS, os resultados foram menos acurados por PAS, porém foram satisfatórios por EDXRF e FAAS. Em geral, os resultados são promissores indicando a viabilidade do método. Contudo, um maior numero de amostras precisa ser analisado para implementar a metodologia.
\end{abstract}

Palavras-chave: Tamanho de partícula; sedimento; análise de componentes principais; regressão por mínimos quadrados parciais; espectroscopia.

\begin{abstract}
The aim of this study was to present a method for sediment texture characterization combining three spectroscopy techniques with multivariate analysis. Specifically, data were used from flame atomic absorption spectroscopy (FAAS), energy dispersive X-ray fluorescence (EDXRF) and photoacoustic spectroscopy (PAS) measurements in superficial lake sediment samples, which were combined with principal component analysis for exploratory data analysis and with partial least square (PLS) regression for indirect estimative of clay and sand textures. It was possible to infer quantitative values of grain size using the data from the three techniques allied with PLS regression, which allowed to obtain implicit information in each data set. The same classifications in accordance with samples texture were verified for all the applied spectroscopic methods. However, the classification by EDXRF or PAS was simpler, faster, cheaper and non destructive when compared with FAAS. In the case of granulometry quantitative prediction by PLS regression, the results for PAS were less accurate, but were satisfactory for EDXRF and FAAS. In general the results are promising, indicating the method viability, although a larger sampling is necessary to implement the methodology.
\end{abstract}

Keywords: Grain size; sediment; principal component analysis; partial least square regression; spectroscopy.

* Universidade Estadual do Centro Oeste, Departamento de Física, Campus CEDETEG, CEP 85040-080, CP 3010, Guarapuava-PR, Brasil.

M fmelquiades@unicentro.br DOI: 10.5935/1984-6835.20140109 


\section{Method for Sediment Texture Characterization Using Spectroscopy Techniques and Multivariate Analysis}

Fábio Luiz Melquiades, ${ }^{\mathrm{a}, *}$ Pedro Pablo González-Borrero, ${ }^{\mathrm{a}}$ Felipe R. dos Santos, ${ }^{\text {a }}$ Wycaro E. D. de Deus, ${ }^{a}$ Miguel Kalwa, ${ }^{\text {b }}$ Sueli P. Quináia ${ }^{b}$

a Universidade Estadual do Centro Oeste, Departamento de Física, Campus CEDETEG, CEP 85040-080, CP 3010, Guarapuava-PR, Brasil.

b Universidade Estadual do Centro Oeste, Departamento de Química, Campus CEDETEG, CEP 85040-080, CP 3010, Guarapuava-PR, Brasil.

* fmelquiades@unicentro.br

1. Introduction

\section{Experimental}

2.1. Study area and collection of sediment samples

2.2. Instrumentation

2.3. Grain Size, $\mathrm{pH}$ and $\mathrm{OM}$ Determination

2.4. Statistical analysis

\section{Results and Discussion}

3.1. Characterization of sediment samples

3.2. Multivariate analysis

3.3. PCA with PAS spectral data

3.4. PLS for texture quantification

\section{Conclusions}

\section{Introduction}

Soil and sediment studies are very important due to their relation to agriculture and the environment. Their physical and chemical properties will determine the specific applications. For these reasons, an interdisciplinary study, considering physics, chemistry, statistics, mineralogy and biology areas, is fundamental. One of the soil and sediment properties of interest is the texture. It refers to the shape, size and threedimensional arrangement of the particles that make up soil and sediment.

The sediment is a major compartment of the aquatic ecosystem, forming a variety of habitats for different organisms. Furthermore, it acts as a medium of concentrating nutrients and contaminants that can contribute as a source for existing organisms in aquatic environment. The 
metals are present in a compartment and may suffer remobilization to the water column. Some of these metals are essential nutrients to the biota, whereas other metals, in higher concentrations, may cause toxic effects to the environment. Thus, the sediments are of utmost importance in environmental impact studies, as a record of permanent contamination effects. ${ }^{1,2}$ Because of the interdisciplinary of soils and sediments, different technique and methodology should be applied for their characterization.

Texture of soil and sediments refers to clay, silt and sand proportion, which indicate its consistence characteristics. From these fractions, clay is the one that has the largest contact surface and represents the larger part of the solid phase. Clay also has the ability to complex or adsorb metals due to its large surface area. Sandy soils and sediments have a granular consistence and present high water permeability. Soil and sediments classified as silt present an intermediate granulometry between clay and sand, and are generally erodible. Silt does not aggregate particles like clay and has small and light particles. ${ }^{3}$

The conventional methodology for texture determination in soils and sediments is densitometry. ${ }^{4}$ In this method the sample is diluted in $\mathrm{NaOH}$ and water and the measurement with hydrometer is performed. Unfortunately, it is a slow and laborious methodology, besides the waste it generates and the destruction of the original samples. ${ }^{5}$

Most of the soil and sediment constituents can be identified and sometimes quantified by the data from different spectroscopic techniques. ${ }^{6}$ The main constituents that influence its spectral behavior are the organic matter, iron oxides, mineralogy, clay content and moisture. Certainly, soil and sediment analysis techniques that are faster, cheaper and allow simultaneous determination of their physicochemical parameters are more advantageous. Besides, in the last years laboratory instrumentation and the feasibility of multivariate statistical methods have advanced and new alternatives to traditional methodologies conducted on soil and sediment analysis could thus be developed. ${ }^{7-}$ 10

Spectroscopic techniques like flame atomic absorption spectroscopy (FAAS) ${ }^{11}$ and energy dispersive $X$-ray fluorescence $(\text { EDXRF })^{12}$ are commonly employed for the determination of metallic ions concentration in soils and sediments, including recent applications with portable XRF in field. ${ }^{13}$ Photoacoustic spectroscopy (PAS), ${ }^{14}$ can be also applied to study the optical absorption spectra of soils. ${ }^{15}$ For FAAS analysis an acid digestion of the samples is necessary, otherwise, for EDXRF and PAS, the samples can be analyzed in powder form after minor preparation. These techniques are not conventionally used for texture determination. However, it is known that metals use to have a greater affinity for smaller particles and organic compounds, i.e. for clay sediments, ${ }^{16}$ but it depends on geochemical conditions.

In the case of EDXRF, the grain size and organic matter (OM) content related to light elements influence the background and enhance the scattering peaks in the spectra. ${ }^{17}$ For example, Rayleigh and Compton scatterings contain information about the average atomic number, particle size and sample density. ${ }^{18}$ In the case of PAS, attention should be paid to the effect of particle size on photoacoustic (PA) signals when powder samples are measured. Previous studies have indicated that the PA band intensities increase with a decrease in particle diameter and that the band intensities ratios are not constant for particles of different diameter. ${ }^{19}$

Because sediment is a complex mixture and the spectra obtained are equally intricate, multivariate analysis techniques could be applied to extract implicit information in the spectra data. Therefore, the magnitude of complex problems that are solved by spectroscopy could be increased by the use of multivariate analysis methods. ${ }^{20,21}$ Multivariate statistical methods are useful for spectra separation based on non 
characteristics information (implicit information). In this case, the application of unsupervised methods, like principal component analysis (PCA) and Hierarchical Cluster Analysis (HCA) are appropriate.

HCA is performed through the determination of distances among the sample data, which can be calculated considering the closest K-neighbor or mean of the samples. The data can be either the original (scaled or centered on the mean) or the scores generated by the PCA. A numeric routine is applied with the objective of sample classification, dividing a set of observations into homogenous groups according to some criteria. The technique is based on distance calculations and the results plotted in a dendogram, which summarize the information. ${ }^{22}$

PCA is applied to standards recognition, explaining the discrepancies between a large number of correlated variables. PCA is also a dimension reduction technique, in which orthogonal transformations in the data are performed to obtain linear combinations of the original variables. The new set of variables, called principal components (PCs), is smaller than the original one and the PCs are uncorrelated, retaining most of the variation in the first few components. ${ }^{7}$ Its representation in score plots is very useful as a display tool for examining the relationships between objects, looking for groups and trends, sorting out outliers. The loading plots display the variables that are responsible for the samples classification.

Besides the samples classification, it is possible to quantify the properties of interest using multivariate regression methods, starting from the values obtained from the conventional methodology. ${ }^{23}$ To do this a very useful method is Partial Least Square (PLS) regression.

PLS regression is a well-known factor analysis applied for parameters prediction, on which is established a quantitative relationship between the set of instrumental responses (for example, spectral data) and one or more physical or chemical properties of the samples (in this study, grain size), developing a mathematical model which correlates such relationship. This procedure involves two steps: calibration and validation. The calibration step establishes a relation between the data matrix $X$ (instrumental signals, independent variables) and the known samples properties from reference samples (dependent variables) organized in $Y$ matrix. The validation allows verifying if the model is capable to predict the properties of new samples. ${ }^{24}$

The main aim of this study is to propose an alternative methodology for texture characterization of surface sediment samples, assessing the combination of spectroscopic analytical techniques with multivariate analysis. Specifically, PCA and HCA were employed for classification and PLS for quantification of clay and sand textures using FAAS, EDXRF and PAS data.

\section{Experimental}

\subsection{Study area and collection of sediment samples}

The study area is located at the Itaipu Lake, at the border of Brazil and Paraguay. This lake is one of the largest dams in the world and its primary objective is to generate electric energy. In addition, the flooded area has multiple uses: navigation, recreation and tourism, fisheries, industrial water abstraction, and urban and agricultural irrigation.

The samples were collected from nine points along the Itaipu Lake (Figure 1). These points are touristic places, known as artificial beaches. Surface sediments (depth $0-5 \mathrm{~cm}$ ) were collected using plastic bottles. On return to the laboratory, the sediments were stored in the dark at $4{ }^{\circ} \mathrm{C}$ before being air-

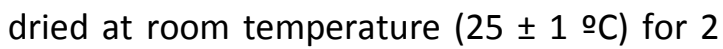
weeks and sieved through a $70-\mu \mathrm{m}$ mesh. ${ }^{25}$ 


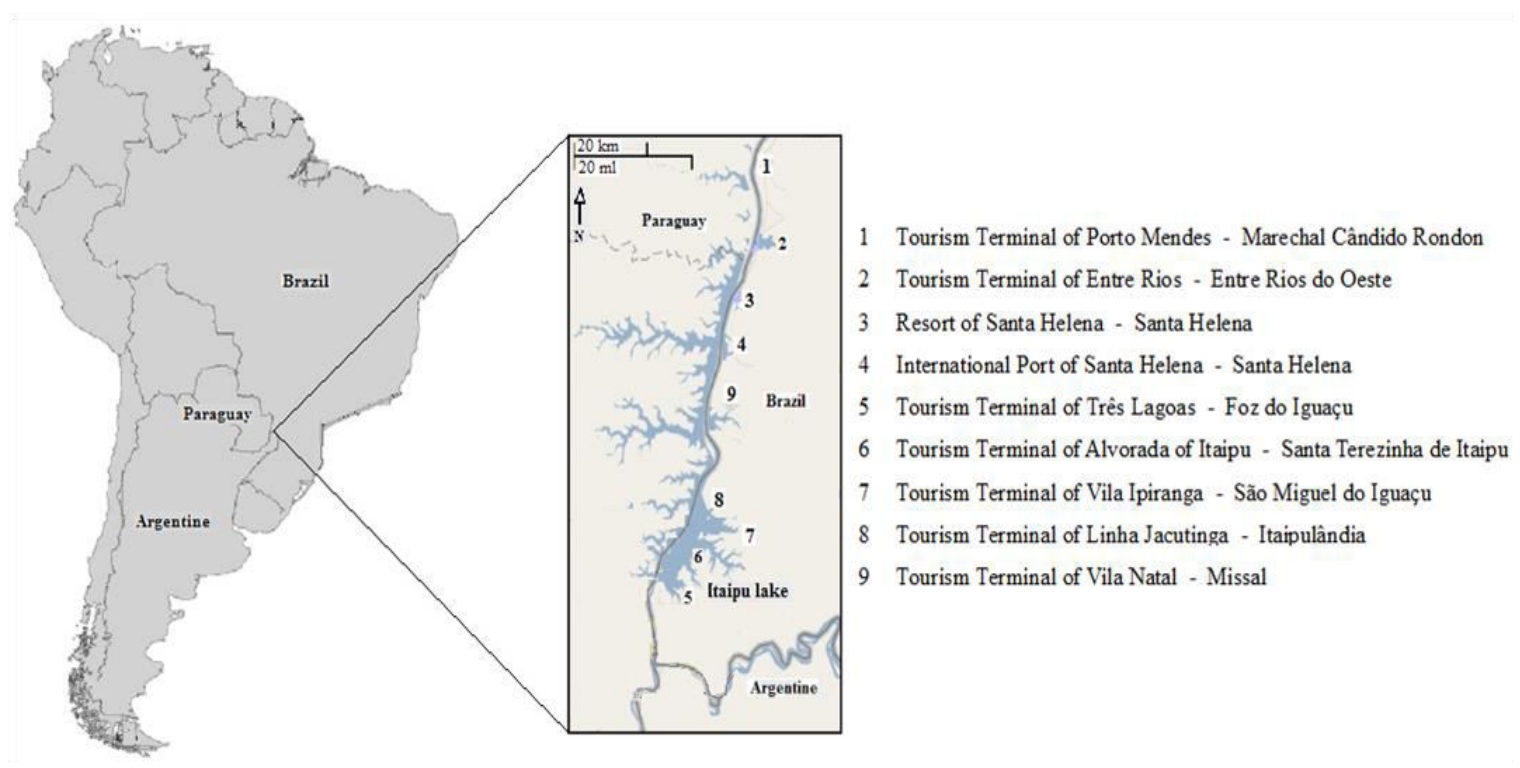

Figure 1. Map from the selected sampling sites (http://maps.google.com)

\subsection{Instrumentation}

The quantification of metallic ions was carried out using FAAS equipment from Varian, model SpectraAA-220, equipped with hollow cathode lamps and deuterium lamp for background correction.

The samples were prepared for pseudototal ions extraction. Metals can be bound to various phases of the sediment: either weakly adsorbed to surface particles like clay and humic acid or strongly bound to the matrix, commonly formed by aluminum silicates. Still exist the intermediate phases bound to carbon, to iron and manganese oxyhydroxy, connected to the OM and also with sulfides. Metals in these phases are weakly bound and could be easily displaced to the water column generating contamination risks. However, metal bound to oxide and refractory materials, which make up the mineral crystalline structure, are imprisoned by extremely strong binding force which cannot be broken by biota metabolic activities. So, metals occluded in this phase are in minor quantity, do not contributing significantly to the sand fraction in which they are bound. ${ }^{26,27}$ Metal interactions with sediment, in the biogeochemical cycle, is strongly affected by particle size. Elements from anthropogenic and natural origin are concentrated in silt and clay fractions, whose granulometry is below $63 \mu \mathrm{m}$. Therefore, a drastic digestion of the sediment is not necessary to establish its metal content, since the metal portion present in the crystalline lattice of the silica particles does not contribute significantly to the total content of metallic elements in the sediments. ${ }^{28}$

All samples were prepared in triplicates. Analytical grade reagents were used in the study. The analysis was accomplished employing analytical curves by means of analytical standards. The solutions of metal ions ( $\mathrm{Al}, \mathrm{Cd}, \mathrm{Cr}, \mathrm{Cu}, \mathrm{Fe}, \mathrm{Mn}, \mathrm{Ni}, \mathrm{Pb}$ and $\mathrm{Zn}$ ) were made by diluting a stock standard solution of $1000 \mathrm{mg} \mathrm{L}^{-1}$ (J. T. Baker Instra Analysed, Mexico City, Mexico) in ultrapure water (TKA Genpure UV, model no 08.2205). The methodology used in the extraction of pseudo-total ions was realized with concentrated analytical-grade $\mathrm{HNO}_{3}$ and $\mathrm{H}_{2} \mathrm{O}_{2}$ (30\% v/v).

Approximate $0.5 \mathrm{~g}$ dry sediment sample was put into a glass vessel, and $15 \mathrm{~mL}$ concentrated $\mathrm{HNO}_{3}$ was added. The glass vessel was heated at $60{ }^{\circ} \mathrm{C}$ for $4 \mathrm{~h}$. Another 8 $\mathrm{mL} \mathrm{H}_{2} \mathrm{O}_{2}(30 \% \mathrm{v} / \mathrm{v})$ was added to the glass 
vessel and maintained at $60^{\circ} \mathrm{C}$ for $2 \mathrm{~h}$. After cooling, the digested sample was decanted into a glass tube and diluted to $50 \mathrm{~mL}$ with deionized water. ${ }^{29}$

Energy Dispersive X-ray Fluorescence spectrometer (Shimadzu EDX 700), with Rh tube and $\mathrm{Si}(\mathrm{Li})$ detector, was used. Measurements were performed in vacuum with $\mathrm{Zr}$ filter at $50 \mathrm{kV}, 500 \mu \mathrm{A}$ and $3 \mathrm{~g}$ of samples in powder form were placed in XRF cups covered with $2.5 \mu \mathrm{m}$ Mylar film for $100 \mathrm{~s}$ irradiation time.

The PAS experiments were performed using a spectrometer consisting of a $1000 \mathrm{~W}$ xenon arc lamp (Oriel Corporation, model $6269)$, the radiation of which was modulated by a variable speed chopper (Stanford Research Systems, model SR540). A monochromator (Oriel, model 77250), in combination with the appropriate absorption filters, was used for wavelength selection and to eliminate higher order diffraction. The beam leaving the monochromator was directed into a home-made PA cell, a small gas-tight enclosure with a condenser microphone (Bruel and Kjaer, model 4392) mounted in one wall. Changes in sample temperature cause alterations of the pressure in the enclosed gas, which are subsequently converted to an electrical signal by the microphone. The signal was preamplified and fed to a lock-in amplifier (SRS, model SR830), which synchronizes the photoacoustic signal with the reference pulse from the chopper. All the photoacoustic spectra were obtained at a modulation frequency of $16 \mathrm{~Hz}$. The lock-in is connected to a microcomputer that controls all the instrumentation. The PA signal was rationed by the signal of carbon black, to eliminate the spectral variation of the illumination source. To improve accuracy, we have repeated all measurements three times.

\subsection{Grain Size, $\mathrm{pH}$ and $\mathrm{OM}$ Determination}

Texture determination of sediment samples (e.g. silt, sand, clay) was performed using densitometry. ${ }^{4,24}$ In the specific case of these samples, the fraction of silt was small and any sample was classified in this category. So, in this study, were explored clay and sand fractions. OM content was determined gravimetrically. ${ }^{25,30}$ One gram of each sediment sample was combusted in a furnace at 500 o $\mathrm{C}$ for $4 \mathrm{~h}$ to determinate weight loss on ignition. Total organic carbon (TOC) content was calculated by the empirical formula Van Bemmelen factor: TOC = OM/ 1.724. The $\mathrm{pH}$ of samples was determined by estimating the activity of $\mathrm{H}^{+}$ ions in the suspension of the sediment. So, 8 $\mathrm{cm}^{3}$ of sediment were transferred to a beaker $(50 \mathrm{~mL})$ with $20 \mathrm{~mL}$ of $\mathrm{CaCl}_{2} 10^{-2} \mathrm{~mol} \mathrm{~L}^{-1}$ to maintain the ionic equilibrium of the solution. The solution was stirred for 15 minutes with the aid of a magnetic stirrer and reading was done by using a $\mathrm{pH}$ meter previously calibrated with buffer solutions $\mathrm{pH}$ 7.0 and 4.0. ${ }^{25}$

\subsection{Statistical analysis}

In this study three different data sets for PCA and PLS evaluation, were used: (a) metallic ion concentration, with $\mathrm{pH}$ and $\mathrm{OM}$ results previously obtained ${ }^{25}$; (b) EDXRF spectral data and (c) PAS spectral data.

For the physicochemical parameters were constructed a $9 \times 11$ matrix of collected samples versus concentration values of $\mathrm{Al}$, $\mathrm{Cd}, \mathrm{Cr}, \mathrm{Cu}, \mathrm{Fe}, \mathrm{Mn}, \mathrm{Ni}, \mathrm{Pb}, \mathrm{Zn}, \mathrm{pH}$ and $\mathrm{OM}$. Auto-scale pre-processing was used in this case, and the results were displayed in biplots. The representation of the scores and loadings in the same graphic is called bi-plot.

Several PCA and HCA models were performed with EDXRF spectra, in different energy ranges $(0-40 \mathrm{keV}, 0-7.5 \mathrm{keV}, 7.5$ - 20 $\mathrm{keV}$ and $20-40 \mathrm{keV})$. However, the most significant results were obtained with the complete spectra, consisting of a matrix of 27 rows ( 9 samples measured 3 times) and 2048 
columns (corresponding to the energy values from 0 to $40 \mathrm{keV}$ ).

PAS spectra were evaluated in the wavelength range of 300 to $1100 \mathrm{~nm}$ and a 9 $x 800$ matrix was used. Both PAS and EDXRF spectra were preprocessed using mean center. The PLS regression were performed with the best PCA models. The calibration set was composed by seven samples and the external validation by two samples, numbers 4 and 5.

All statistical analysis and calculations were performed with software Matlab with PLS ToolBox version 5.8.

\section{Results and Discussion}

3.1. PCA with metallic ion concentration, $\mathrm{pH}$ and $\mathrm{OM}$

Metallic ion concentration, granulometry, $\mathrm{pH}$ and $\mathrm{OM}$ values were determined in a previous study ${ }^{25}$. Results of the analysis of physicochemical parameters of sediment samples are listed in Table 1.

Table 1. Physicochemical parameters of superficial sediment in Itaipu Lake (adapted from reference 25)

\begin{tabular}{|c|c|c|c|c|c|}
\hline \multirow{2}{*}{ Points } & \multicolumn{3}{|c|}{ Granulometric Fraction $\left(\mathrm{g} \mathrm{kg}^{-1}\right)$} & $\mathrm{pH}$ & $\mathrm{OM}(\%)$ \\
\cline { 2 - 6 } & Sand & Clay & Silt & & \\
\hline 1 & 704 & 248 & 48 & 6.63 & 3.07 \\
\hline 2 & 358 & 477 & 165 & 5.91 & 12.19 \\
\hline 3 & 910 & 89 & 1 & 7.20 & 1.41 \\
\hline 4 & 174 & 670 & 156 & 6.98 & 7.36 \\
\hline 5 & 765 & 211 & 24 & 5.31 & 3.80 \\
\hline 6 & 156 & 819 & 25 & 6.06 & 11.16 \\
\hline 7 & 72 & 782 & 146 & 6.46 & 13.92 \\
\hline 8 & 838 & 144 & 18 & 5.79 & 2.65 \\
\hline 9 & 294 & 596 & 109 & 6.88 & 10.48 \\
\hline
\end{tabular}

The PCA with the present data provided the classification into two groups in the first principal component (Figure 2). Comparing the samples texture classification obtained by densitometry, with the two groups of the PCA, the same division into clay and sand samples was observed. The explained variance was about $75 \%$ in the first two PCs. Samples 2, 4, 6, 7 and 9, grouped at the right side of the biplot, are considered to be composed mainly by clay particles (according to Table 1 results), showing the affinity of metals by clay sediment and consequently with those with higher levels of organic matter.

\subsection{PCA with EDXRF spectral data}

EDXRF spectra (Figure 3) present several kinds of information. Explicitly, the net area of the peaks is related to the concentration of each corresponding element. Implicitly the scattering peaks are related to matrix effects from the samples, and in this case, specifically with OM concentration and grain size. All the spectra are visually similar. They present small differences in the scattering regions and in the intensity of the main peaks. PCA is capable to identify and highlight these differences, allowing a direct interpretation of the characteristics of interest. 


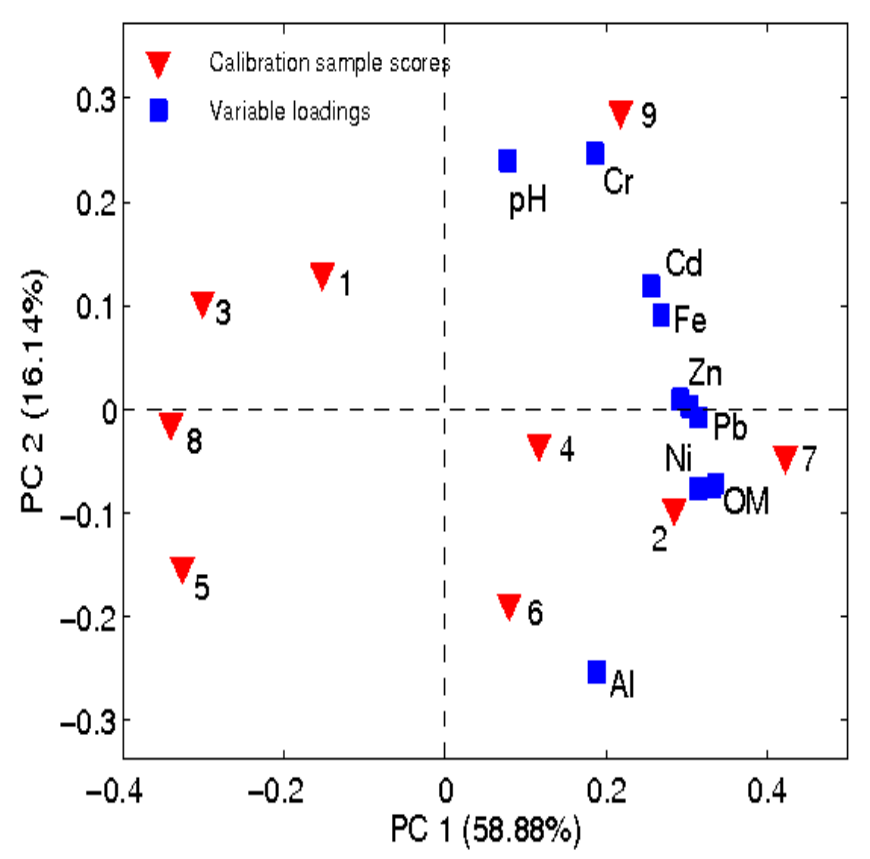

Figure 2. Biplot with $\mathrm{pH}$, organic matter and metallic ion concentration obtained with FAAS

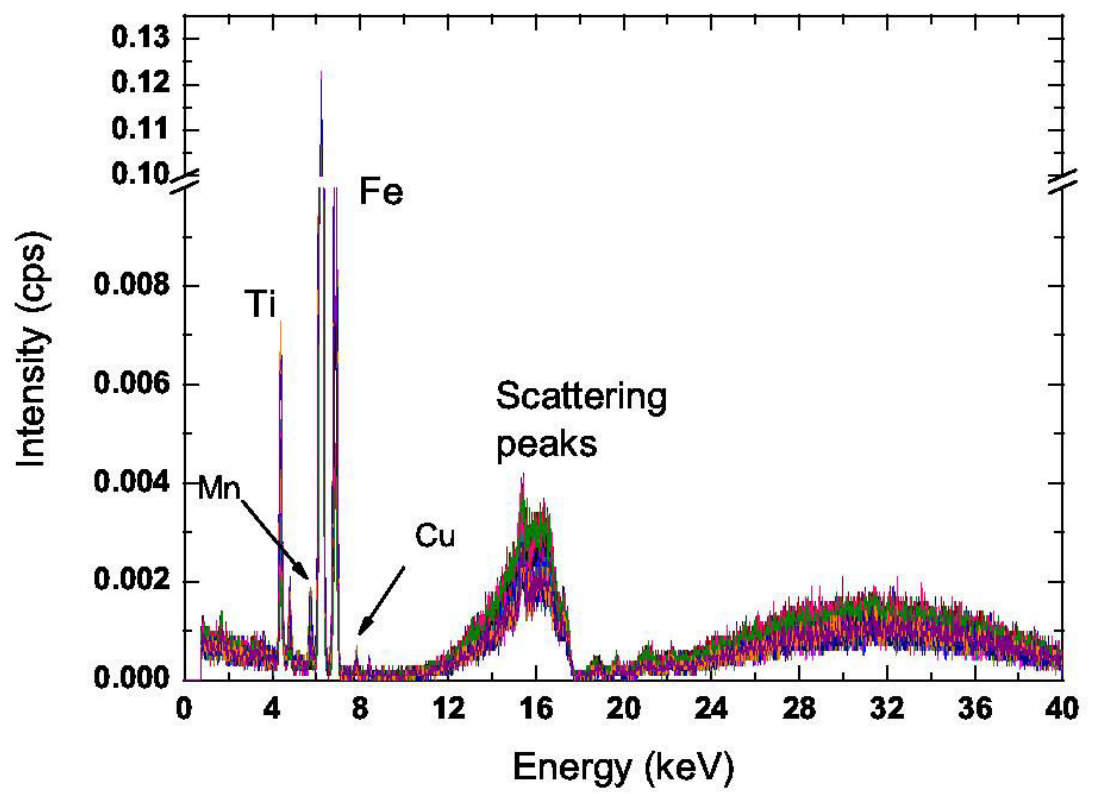

Figure 3. EDXRF spectra from all the measurements of superficial sediment samples. The main elements and the Rayleigh and Compton scattering peaks from the $\mathrm{Zr}$ filter used in the X-ray tube, were identified. Different colors refers to each measurement of the samples 
PCA was achieved with the complete EDXRF spectra. The score plot is illustrated in Figure 4a. PC1 explains $~ 99.3 \%$ of data variance, while PC2 explains $\sim 0.1 \%$. The loadings plot analysis (not presented) shows that the Fe peak was responsible for the classification, where the samples at right, in the positive direction of $\mathrm{PC} 1$, have a higher $\mathrm{Fe}$ concentration. In the PC2, the Ti peak was the one that influenced the separation. This score plot also exhibits the samples classification by grain size and OM content, i.e. samples in the positive side of PC1 are clayey and have a higher OM content. The samples in the negative side of this axis are sandy. This result is comparable to that reported by Förstner and Wittmann, (1981), ${ }^{31}$ in which metallic ions have affinity to sediments with small grain size and high OM content. The HCA for the same data set used in the PCA is presented in Figure $4 \mathrm{~b}$. The separation into clay and sand samples is in accordance with the PCA, corroborating the results.

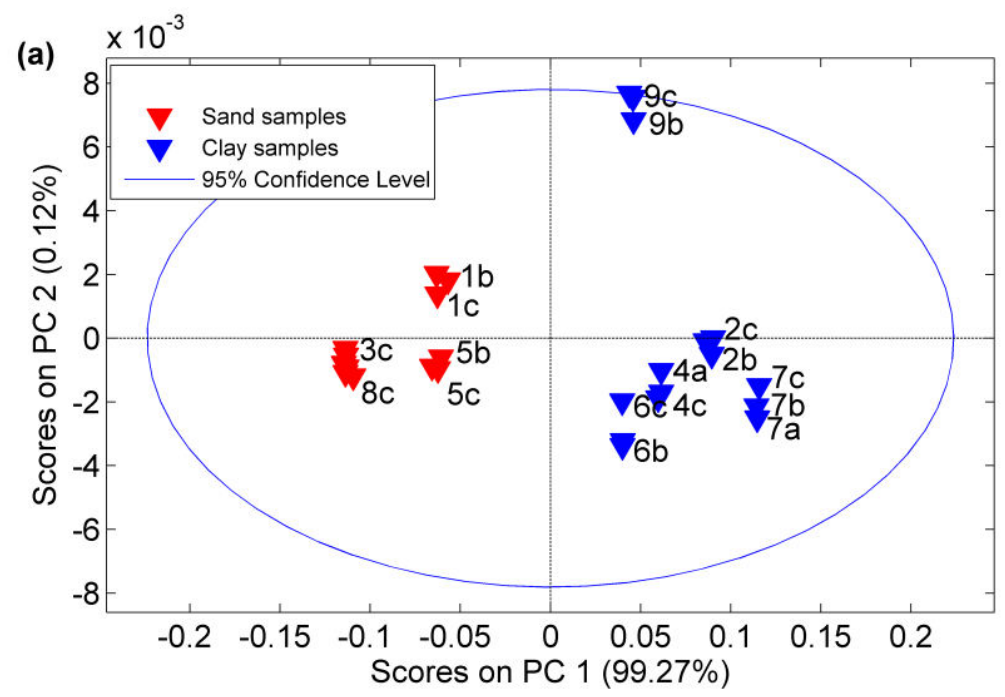

(b)

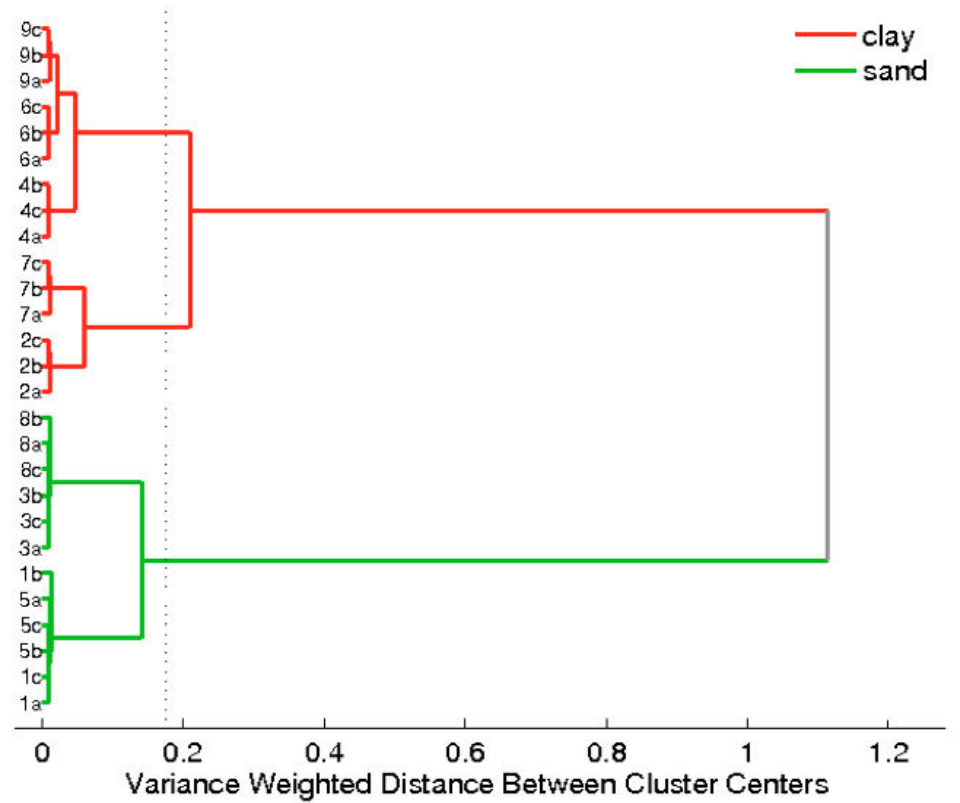

Figure 4. (a) Score plot from PCA analysis and (b) Hierarchical Cluster Analysis plot, both with EDXRF spectral data. The codes $a, b$ and $c$ refers to three measurements performed in each sample 


\subsection{PCA with PAS spectral data}

PA spectra were obtained in the region from 300 to $1100 \mathrm{~nm}$. Figure 5a depicts the spectrum for each sample. Here can be observed that there is saturation tendency of PA signal in spectra range of about $550 \mathrm{~nm}$ to $300 \mathrm{~nm}$. This is an indication of the presence of high OM concentration and iron-based compounds. Samples 1, 3 and 8 show a lower absorption in the wavelength range 300-700 $\mathrm{nm}$, indicating that they have a higher sand composition. The sand particles reflect the incident light, thus giving rise to a lower absorption and consequently a decrease of the photoacoustic signal. For the same reason those samples exhibit smaller baseline values. In the case of sample 5 , in spite of being classified as sand by the conventional method (see Table 1), a different behavior is shown when compare to samples 1,3 and 8 .
We believe that this behavior is due to its higher OM content and higher iron concentration (Table 1). The baseline value is related to the capacity of light absorption and heat retention by the samples. In order to eliminate this effect, this value was subtracted from each PA spectrum (see Fig. $5 b)$. The observed bands, in the near infrared (NIR) region (800-110 $\mathrm{nm}$ ), are attributed to presence of iron-based compounds. It can be noted that samples 2, 9 and 5 show more defined peaks in the NIR region due to the higher content of iron.31 In the case of sample 7, despite its higher iron content, those peaks are not well defined, probably, because of its high OM content in relation to the Fe content (Table 1). These reasons may also explain the spectrum behavior of sample 4 and 6 in the NIR region. In order to obtain additional information from the PA spectra, a multivariate analysis was performed.

(a)

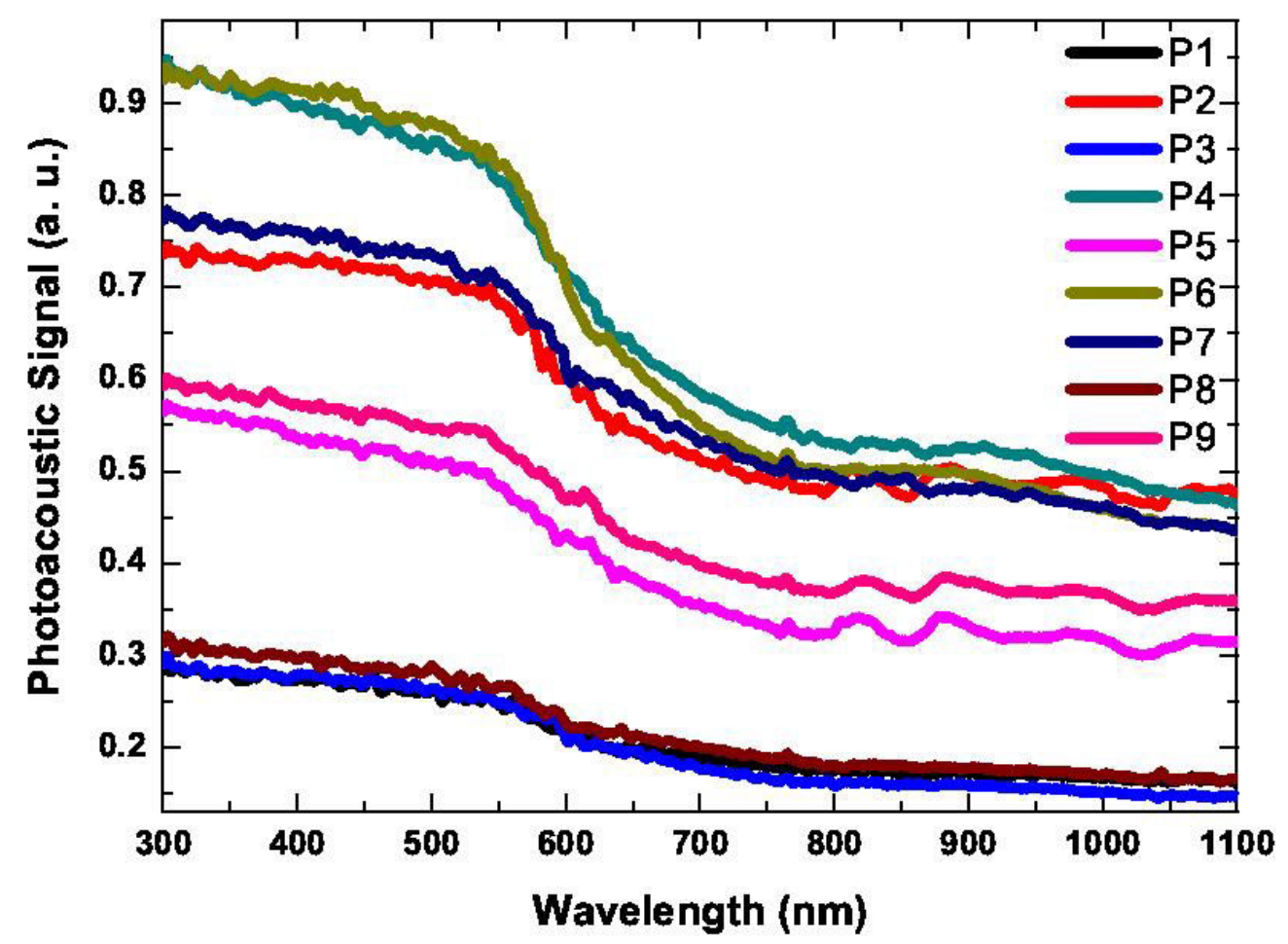

(b) 


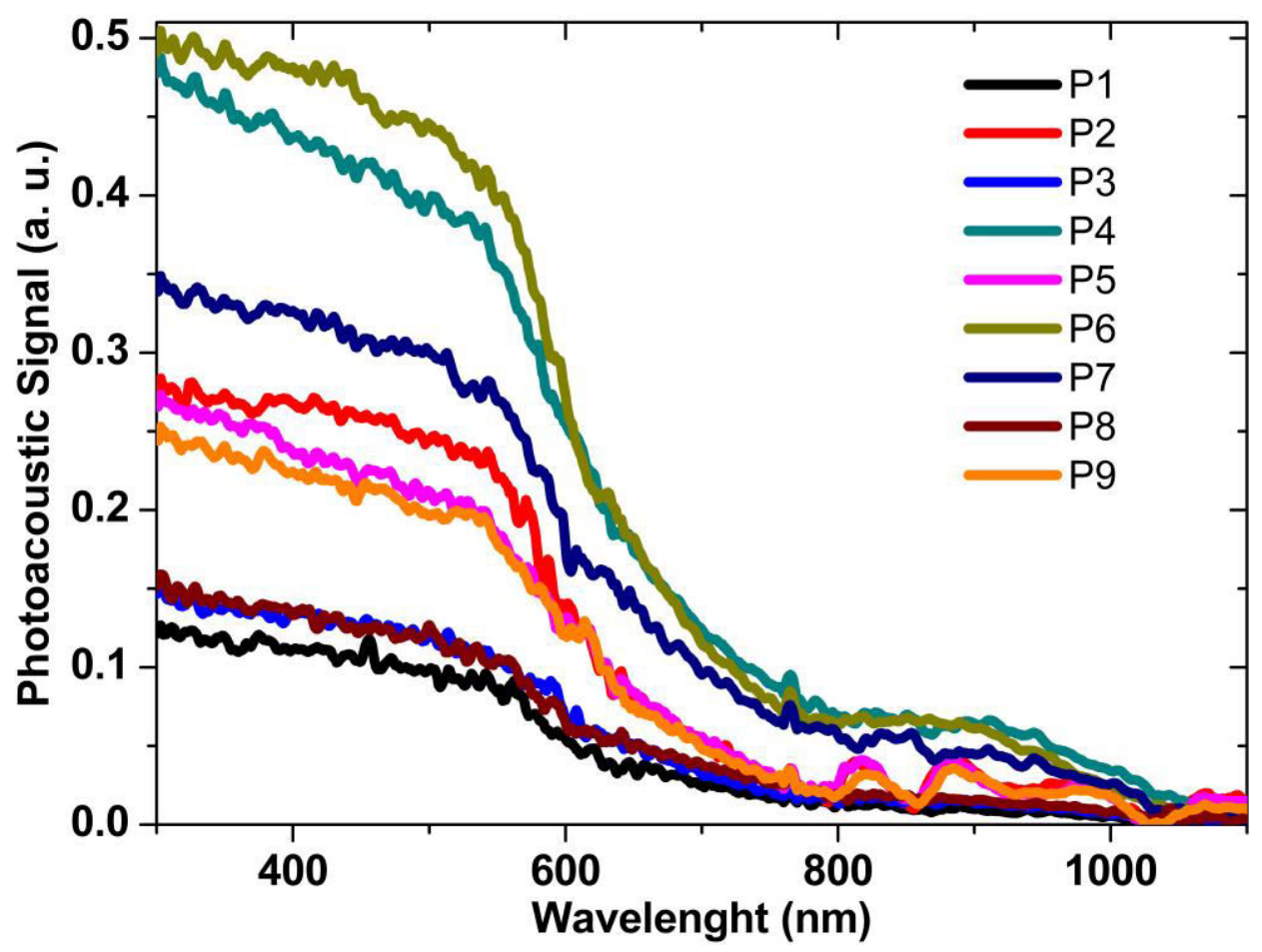

Figure 5. Typical photoacoustic spectrum of sediment samples from Itaipu Lake: (a) measured and (b) without baseline

PCA was performed on the matrix data from the PA spectra, using mean center preprocessing. The PCA score plot (Figure 6) (with $99.90 \%$ of the total variance in the first two principal components) presents the sample separation. Two natural groups were formed in this two-dimensional space: the first group consisted of the sand sample on the negative side of the first principal component. The second group was formed with the clay samples on the more positive side of the first principal component. The second principal component plays a major influence on clay samples, as they are more disperse vertically.

The examination of the loadings from the first two principal components suggested that the clay samples have a higher intensity in the PA spectra, what is confirmed in Figure 6. 


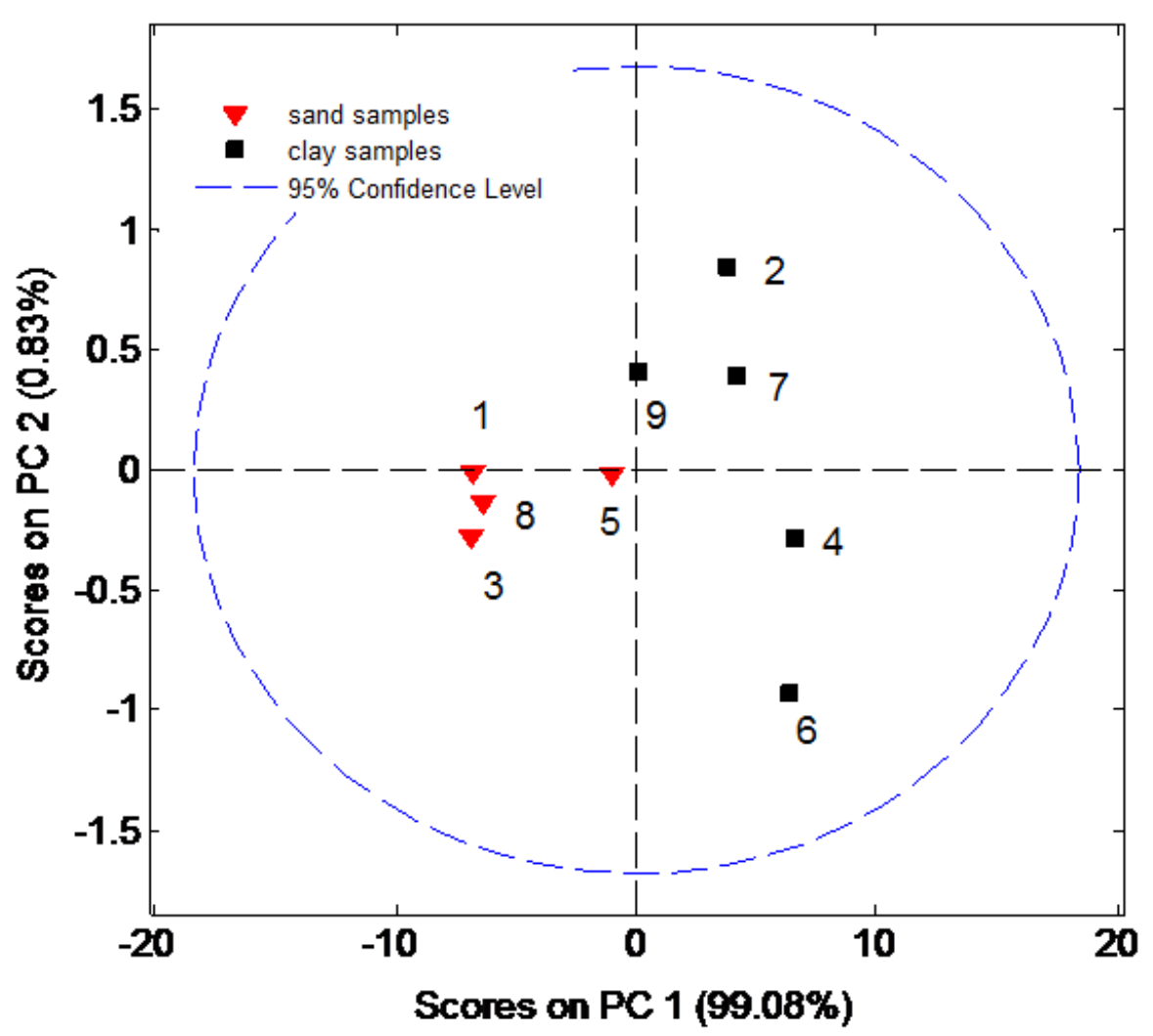

Figure 6. Score plot of the first two principal components using PAS spectral data

\subsection{PLS for texture quantification}

The quantification of sand and clay content in the samples were predicted by PLS regression with the three set of spectroscopic data for $X$ matrix: physicochemical parameters $(\mathrm{pH}, \mathrm{OM}$ and FAAS metal concentration); EDXRF spectra and PAS spectra. For $Y$ matrix were used the texture values obtained by the conventional methodology (Table 1). The regression curves and the predicted values (samples 4 and 5) are presented in Figure 7. In this figure the error bars were generated by the PLS model based on the residues in the regression calculation. In the case of the calibration set, the residues were calculated by the leave one out process. For the validation set, the error bar is due to the residues in the regression calculation for the two points of external validation. The correlation coefficients for calibration of the regressions ranged from 0.990 to 0.804 . The relative deviation (RD) for prediction was calculated with respect to the measured values. Its RD values varied from $3 \%$ to $7 \%$ for FAAS, except for the value $174 \mathrm{~g}$ $\mathrm{kg}^{-1}$ whose deviation was $73 \%$. The RD ranged from $6 \%$ to $52 \%$ for EDXRF prediction and from $23 \%$ to $110 \%$ for PAS. We believe that the high RD values are because of the low predictability of the PLS regression models, due to the fact that, the restrict number of samples do not make possible the satisfactory choice of calibration and prediction sets. The prediction was less accurate for PAS data, whereas the results were most satisfactory for FAAS and EDXRF evaluation. However, the results demonstrate the potential of the spectroscopic techniques for granulometry quantification. 
FAAS

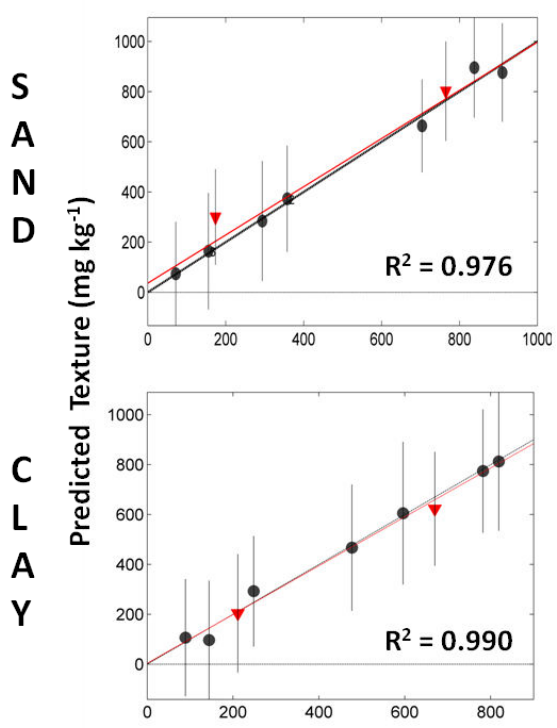

PAS
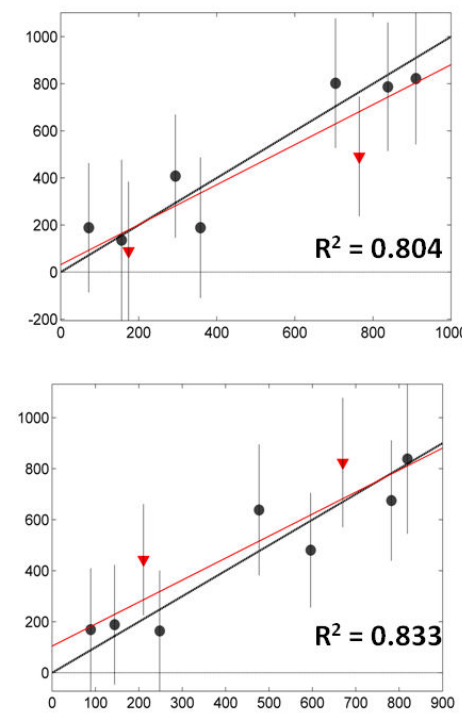

Measured Texture $\left(\mathrm{mg} \mathrm{kg}^{-1}\right)$
EDXRF
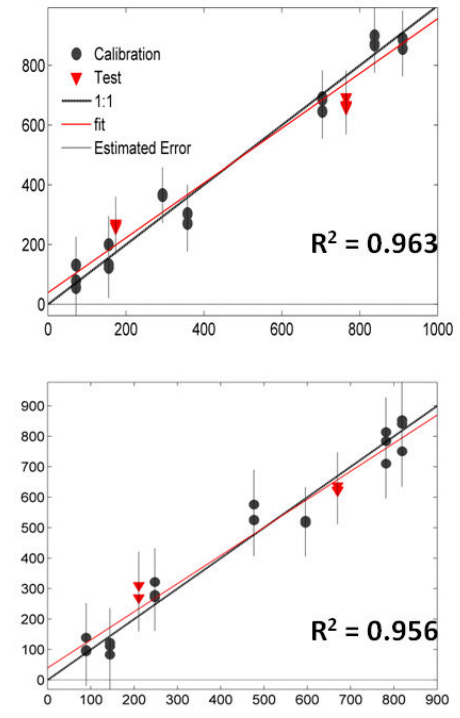

Figure 7. PLS regression curves for sand and clay texture quantification obtained from FAAS concentration values, PAS spectra and EDXRF spectra. The error bars are generated by each

PLS model

\section{Conclusions}

The texture of superficial sediments was classified indirectly using FAAS, EDXRF and PAS techniques in combination with PCA and HCA. The same classification into samples with major contents of clay and sand particles were obtained for all the applied spectroscopic methods. Scores plot indicates that the multivariate analysis can be used for qualitative classification of sediment texture either with spectral data of EDXRF or PAS, or with metallic ion concentration determined by FAAS.

In addition, a quantitative prediction was performed with PLS regression and the results were satisfactory, especially for FAAS and EDXRF data. In the case of PAS, it was not possible to predict accurately the particle size values. The obtained PLS models, at this point, due to the limited number of collection points (only nine), could be considered as a regional modeling, i.e., the prediction models generated are limited and valid for the studied environment. However, a larger number of samples is necessary to implement the methodology and change the robust model statistically.

Our results indicate that the combination of these tools (spectroscopy and multivariate analysis) allows to assess implicit information of the spectral data and to conclude that the presented methodology is feasible. Moreover, the texture classification and quantification could be implemented in soil analysis when these techniques are applied. However, the possibility of texture analysis by EDXRF or PAS, indirectly and combined with multivariate analysis, is simpler, faster, cheaper and non destructive, without residues generation compared with FAAS and other conventional methods. This opens up the possibility of performing fast characterization in soil and sediment properties with an environmentally friendly methodology and could be applied in several areas such as agriculture, geophysics and mineralogy. 


\section{Acknowledgment}

This work was supported by the Brazilian Agencies CNPq and Fundação Araucária. One of the authors (FLM) gratefully acknowledges Dra. Maria Izabel Maretti Silveira Bueno for her collaboration in EDXRF measurements and multivariate analysis.

\section{References}

${ }^{1}$ Schnitzler, D. C.; Grassi, M. T.; Quinaia, S. P. Aplicação de planejamento fatorial a protocolo de extração e fixação de sulfetos volatilizáveis por acidificação (SVA) em amostras de sedimento. Quimica Nova 2009, 32, 1315. [CrossRef]

${ }^{2}$ Belo, A.; Quináia, S. P.; Pletsch, A. L. Avaliação da contaminação de metais em sedimentos superficiais das praias do lago de Itaipu. Quimica Nova 2010, 33, 613. [CrossRef]

${ }^{3}$ Sly P. G. Sediment dispersion: part 1, fine sediments and significance of the silt/clay ratio. Sediment/Water Interactions 1989, 50, 99.

${ }^{4}$ Gee, G. W.; Bauder, J. W. Methods of soil analysis: part I, 2nd ed. American Society of Agronomy: Madison, 1986.

${ }^{5}$ Morón, A.; García, A.; Sawchik, J.; Cozzolino, D. Preliminary study on the use of nearinfrared reflectance spectroscopy to assess nitrogen content of undried wheat plants. Journal of the Science of Food and Agriculture 2007, 87, 147. [CrossRef]

${ }^{6}$ Viscarra Rossel, R. A.; Walvoort, D. J. J.; McBratney, A. B.; Janik, L. J.; Skjemstad, J. O. Visible, near infrared, mid infrared or combined diffuse reflectance spectroscopy for simultaneous assessment of various soil properties. Geoderma 2006, 131, 59. [CrossRef]

${ }^{7}$ Singh, V.; Agrawal, H. M.; Joshi, G. C.; Sudershan, M.; Sinha, A. K. Elemental profile of agricultural soil by the EDXRF technique and use of the Principal Component Analysis (PCA) method to interpret the complex data.
Applied Radiation and Isotopes 2011, 69, 969. [CrossRef]

${ }^{8}$ Comero S.; Locoro G.; Free G.; Vaccaro S.; Capitani L.; Gawlik B. M. Characterisation of Alpine lake sediments using multivariate statistical techniques. Chemometrics and Intelligent Laboratory Systems 2011, 107, 24. [CrossRef]

${ }^{9}$ Mouazen, A. M.; Kuang, B.; De Baerdemaeker, J.; Ramon, H. Comparison among principal component, partial least squares and back propagation neural network analyses for accuracy of measurement of selected soil properties with visible and near infrared spectroscopy. Geoderma 2011, 158, 23. [CrossRef]

${ }^{10} \mathrm{Du}, \mathrm{C}$.; Linker, R.; Shaviv, A. Identification of agricultural Mediterranean soils using midinfrared photoacoustic spectroscopy. Geoderma 2008, 143, 85. [CrossRef]

${ }^{11}$ Welz, B.; Sperling, M.; Resano, M. Atomic absorption spectrometry. Willey-VCH: Wienheim, 1999.

${ }^{12}$ Van Grieken, R. E.; Markowicz, A. A. Handbook of X-Ray Spectrometry, 2th ed. Marcel Dekker Inc: New York, 2002.

${ }^{13}$ McLaren T. I.; Guppy C. N.; Tighe M. K.; Foster N.; Grave, P.; Lisle L. M.; Bennett J. W. A Rapid and Nondestructive Plant Nutrient Analysis using Portable X-Ray Fluorescence. Soil Science Society of America Journal 2012, 76, 1436. [CrossRef]

${ }^{14}$ Rosencwaig, A. Photoacoustics and photoacoustic spectroscopy chemical analysis. R. E. Krieger Publishing Company: Malabar, 1990.

${ }^{15}$ Santos, D. R.; Toledo, R.; Massunga, M. S. O.; Carrió, J. G.; Auler, L. T.; Silva, E. C.; Garcia-Quiroz, A.; Vagas, H. Photoacoustic spectroscopy applied to the study of clay soils. Review of Scientific Instruments 2003, 74, 355. [CrossRef]

${ }^{16}$ Tremblay, L.; Gagné, J. P.; Distribution and biogeochemistry of sedimentary humic substances in the St. Lawrence Estuary and the Saguenay Fjord, Québec. Organic Geochemistry 2007, 38, 682. [CrossRef]

${ }^{17}$ Bueno, M. I. M. S.; Castro, M. T. P. O.; Souza, A. M.; Oliveira, E. B. S.; Teixeira, A. P. $X$-ray scattering processes and chemometrics 
for differentiating complex samples using conventional EDXRF equipment. Chemometrics and Intelligent Laboratory Systems 2005, 78, 96. [CrossRef]

${ }^{18}$ Kessler, T.; Hoffmann, P.; Greve, T.; Ortner, $H$. M. Optimization of the identification of chemical compounds by energy-dispersive $x$ ray fluorescence spectrometry and subsequent multivariate analysis. X-Ray Spectrometry 2002, 31, 383. [CrossRef]

${ }^{19}$ Yang C. Q.; Fately W. G. Optimization of the identification of chemical compounds by energy-dispersive $\quad x$-ray fluorescence spectrometry and subsequent multivariate analysis. Journal of Molecular Structure 1986, 141, 279. [CrossRef]

${ }^{20}$ Kaniu, I. M.; Angeyo, H. K.; Mangala, J. M.; Mwala, K. A.; Bartilol S. K. Feasibility for chemometric energy dispersive X-ray fluorescence and scattering (EDXRFS) spectroscopy method for rapid soil quality assessment. X-Ray Spectrometry 2011, 40, 432. [CrossRef]

${ }^{21}$ Ben-Dor, E.; Heller, D.; Chudnovsky, A. A Novel Method of Classifying Soil Profiles in the Field using Optical Means. Soil Science Society of America Journal 2008, 72, 1113. [CrossRef]

${ }^{22}$ Matthias, O.; Chemometrics: Statistics and computer application in analytical chemistry, Wiley-VHC: Weinheim, 1999.

${ }^{23}$ Zhu, Y.; Weindorf, D. C.; Zhang, W. Characterizing soils using a portable X-ray fluorescence spectrometer: 1 . Soil texture. Geoderma 2011, 167-168, 167. [CrossRef]

${ }^{24}$ Massart, D. L., Vandeginste, B. G. M., Buydens, S. J.; Lewi, P. J.; Smeyers-Verbeke,
J.; Handbook of Chemometrics and Qualimetrics: Parte B., Elsevier: Amsterdam, 1997.

${ }^{25}$ Kalwa, M.; Quináia, S. P.; Pletsch, A. L.; Techy, L.; Felsner, M. L. Fractionation and Potential Toxic Risk of Metals From Superficial Sediment in Itaipu LakeBoundary Between Brazil and Paraguay. Archives of Environmental Contamination and Toxicology 2013, 64, 12. [CrossRef]

${ }^{26}$ Clemente, E. P.; Schaefer C. E. R. G.; Oliveira, F. S.; Marciano, L. C.; Clemente, A. D. Geoquímica dos solos da llha da Trindade, Atlântico Sul, Brasil. Geociência. 2012, 31, 31. ${ }^{27}$ Quinaia, S. P., Cavagnoli, A. R.; Martins, V. J. Avaliação da distribuição de $\mathrm{Cr}$, $\mathrm{Pb}$ e $\mathrm{Cu}$ em sedimentos superficiais. Revista Ciências Exatas e Naturais 2009, 11, 49.

${ }^{28}$ Fadigas, F. S.; Amaral-Sobrinho, N. M. B; Mazur, N.; Anjos, L. H. C.; Freixo, A. A. Concentrações naturais de metais pesados em algumas classes de solos brasileiros. Bragantia 2002, 61, 151. [CrossRef]

${ }^{29}$ Cotta, J.; Rezende, M.; Piovani, M. R. Avaliação do teor de metais em sedimento do Rio Betari no Parque Estadual Turístico do Alto Ribeira-PETAR. Química Nova 2006, 29, 40. [CrossRef]

${ }^{30}$ American Public Health Association; Standard methods for the examination of water and wastewater, 21st ed. APHA:Washington, DC, 2001.

${ }^{31}$ Förstner, U.; Wittmann, G. T. W.; Metal pollution in the aquatic environment, 2th ed. Springer-Verlag: New York, 1981. [CrossRef] 